\title{
THE IMPLEMENTATION OF FAIR VALUE ON SHORT TERM ASSESMENT OF BIOLOGICAL ASSETS
}

\author{
Murtianingsih \\ Anas Hari Setiawan \\ Sekolah Tinggi Ilmu Ekonomi Asia Malang
}

\begin{abstract}
This study aims to identify and analyze the implementation of fair value and the impact of the use of bases the recognition, measurement, and disclosure of the biological assets with the object of research PT. Malindo Feedmill Tbk which further research is also useful for agriculture companies in managerial decision making. This research is descriptive quantitative concluded based on data and clarify the picture of the implementation of fair value is based on International Accounting Standard (IAS) 41 and perform comparative measurements of biological assets PT. Malindo Feedmill, Tbk based acquisition price. From the results of this study concluded that the difference in the material due to fair value measurement that refers to IAS 41 in determining the market value following the fluctuations of the market, but in IAS 41 does not distinguish between fair value treatment against several categories of biological assets. This is certainly less relevant when applied to some types of biological assets, such as short term biological assets at PT. Malindo Feedmill Tbk.
\end{abstract}

Keywords: biological assets, fair value, historical cost, ias 41

Abstrak: Penelitian ini bertujuan untuk mengetahui dan menganalisa implementasi fair value serta dampak dari penggunaan basis pengakuan, pengukuran, dan pengungkapannya terhadap asset biologis dengan obyek penelitian PT. Malindo Feedmill, Tbk yang selanjutnya penelitian ini juga bermanfaat untuk perusahaan agriculture dalam pengambilan keputusan manajerial. Jenis penelitian ini merupakan diskriptif kuantitatif yaitu menyimpulkan berdasarkan data dan menjelaskan gambaran implementasi fair value berdasarkan International Accounting Standard (IAS) 41 dan melakukan perbandingan pengukuran asset biologis PT. Malindo Feedmill, Tbk yang berbasis harga perolehan. Dari Hasil penelitian dapat disimpulkan adanya perbedaan yang material dalam pengukurannya karena fair value yang mengacu pada IAS 41 dalam penentuan nilai pasar mengikuti fluktuasi pasar, namun dalam IAS 41 tidak membedakan perlakuan fair value terhadap beberapa kategori biological asset. Hal ini tentunya kurang relevan apabila diterapkan terhadap beberapa jenis biological asset, misalnya seperti short term biological asset pada PT. Malindo Feedmill, Tbk.

Kata Kunci: aset biologis, fair value, historical cost, ias 41

Globalisasi membawa dampak hilangnya batas-batas geografis antar negara, sehingga dalam kegiatan perekonomian menuntut adanya sistem akuntansi dan pelaporan keuangan yang seragam dan dapat diterima oleh berbagai negara. Atas dasar itu dibentuklah suatu standar yang bernama International Financial Reporting Standard (IFRS) sebagai suatu standar umum dalam usaha harmonisasi standar akuntansi 
keuangan. Indonesia sebagai salah satu negara berkembang juga mengambil sikap untuk melakukan harmonisasi Standar Akuntansi Keuangan (SAK) terhadap IFRS sejak tahun 2002. Namun sejak tahun 2012, Dewan Standar Akuntansi Keuangan (DSAK) mengambil kebijakan mulai melakukan konvergensi SAK terhadap IFRS.

Konvergensi IFRS membawa dampak perubahan pengukuran dan pengungkapan terhadap pelaporan keuangan. Sebelumnya telah diketahui sejak lama Indonesia menggunakan konsep historical cost sebagai basis pengukurannya. Konsep historical cost menurut Suwardjono (2008:475) adalah rupiah kesepakatan atau harga pertukaran yang telah tercatat dalam pembukuan. Dalam konsep historical cost, pos-pos laporan keuangan diukur berdasarkan harga perolehan pada saat terjadinya transaksi. Penggunaan harga perolehan nantinya akan menghasilkan perhitungan nilai buku yang dijadikan dasar acuan dalam menilai perusahaan.

Sonbay (2010) berpendapat bahwa dengan menggunakan historical costing dapat mengurangi aspek kualitas relevansi. Hal ini disebabkan historical cost tidak bisa mengakui perubahan nilai riil dari transaksi yang telah terjadi. Penyusunan laporan keuangan yang didasarkan historical cost ini menyebabkan laporan keuangan kehilangan keakuratan maupun ketelitiannya. Pada akhirnya, informasi dalam laporan keuangan tersebut kurang relevan apabila digunakan sebagai dasar pengambilan suatu keputusan. Seperti halnya penelitian Stickney, Well, Schipper and Francis (2006) menyatakan; In the financial Industry, for example, certain assets, such as securities that have been labeled trading securities or available for sale securities, may either appreciate or depreciate accourding to market movement and have always been subject to market based pricing. Howover, the values can only decline for securities labeled as held- to -maturity securities. Hal ini menggambarkan bahwa historical cost tidak dapat menggambarkan kondisi keuangan yang sebenarnya. Nilai yang tidak relevan akan berdampak pada laporan keuangan baik neraca, laporan laba rugi maupun arus kas.

Setelah konvergensi terhadap IFRS mulai diterapkan, Indonesia diperkenalkan konsep fair value sebagai basis pengukuran terbaru atas pelaporan keuangan saat ini. Fair value dapat didefinisikan sebagai harga yang diterima atas penjualan aset atau pembayaran untuk mentransfer liabilitas dalam transaksi antar pihak yang berkepentingan pada tanggal pengukuran (IFRS 13 par. 9). Penerapan fair value dinilai 
dapat meningkatkan akuntabilitas informasi keuangan karena hasil yang ditampilkan mendekati keadaan yang sebenarnya terjadi.

Standar IFRS yang menggunakan basis pengukuran fair value diantaranya adalah International Accounting Standart (IAS) 41. IAS 41 mengatur perlakuan akuntansi, penyajian dan pengungkapan laporan keuangan yang terkait dengan aktiva biologis dan produk pertanian pada saat masa panen sejauh ada kaitannya dengan kegiatan pertanian (Greuning, 2005:301). Biological asset harus dinilai pada saat perolehannya dan pada setiap akhir periode pelaporan dengan menggunakan fair value dikurangi biaya untuk menjual (IAS 41 par. 12). Selisih keuntungan atau kerugian atas penilaian biological asset diakui sebagai bagian dari laba rugi tahun berjalan.

Oliveira, Jonas Da Silva et al, (2015); mind finding indicate that market values for dairy production animals are inconsistent, reducing financial information comparability levels. To solve these problems, the authors propose a new models to asses fair value based on the net present value (NPV) of future cash-flows. This is a possible method to measure bovines that are in a breading stage and it will assure the comparability of financial statement among dairy farm.

Widyastuti (2012) berpendapat bahwa perusahaan harus menentukan nilai wajar dari aset biologis secara andal, jika nilai wajar aset biologis tidak dapat ditentukan secara handal, maka penentuan nilai wajar untuk aset biologis ditentukan dengan mengelompokkan sesuai dengan usia atau kualitas dari aset biologis tersebut. Hal ini sesuai dengan pernyataan IAS 41 par. 45 yang menjelaskan bahwa biological asset dapat diklasifikasikan menjadi mature biological asset dan immature biological asset. Mature biological asset adalah aset yang telah mencapai spesifikasi untuk dipanen, sedangkan immature biological asset dapat dikatakan sebagai aset yang masih belum matang/dewasa untuk bisa dipanen.

IAS 41 par.17 menyatakan bahwa jika terdapat pasar aktif untuk biological asset atau agriculture produce sesuai dengan lokasi dan kondisinya saat ini, harga yang dikutip dari pasar tersebut adalah dasar yang tepat untuk menentukan fair value dari aset tersebut. Sedangkan IAS 41 par. 18 menyatakan jika tidak terdapat pasar aktif, maka perusahaan menggunakan satu atau lebih dasar berikut ini untuk menentukan fair value diantaranya, (1) recent market transaction price, (2) market price untuk aset sejenis dengan penyesuaian untuk mencerminkan perbedaan, dan (3) patokan sektor. 
Ketidaksediaan pasar aktif dari biological asset juga membuat perusahaan terkadang harus membutuhkan jasa apprisal dalam menentukan fair value.

IAS 41 sebagai salah satu standar keuangan yang masih berupa exposure draft membuat sejumlah agricultural company di Indonesia belum bisa menerapkan standar tersebut, salah satunya adalah PT. Malindo Feedmill, Tbk yang merupakan salah satu perusahaan yang memproduksi dan mendistribusikan pakan ternak terbesar di Indonesia, disamping itu perusahaan juga berinvestasi dan mengembangkan bisnis dengan memproduksi bibit ayam (day on chicken), ayam ras pedaging (broiler) dan makanan olahan. Biological asset yang dimiliki oleh PT. Malindo Feedmill, Tbk berupa unggas (ayam) yang memiliki masa transformasi biologis kurang dari 1 (satu) tahun. Sesuai dengan sifatnya, biological asset tersebut dapat diklasifikasikan ke dalam current asset sebagai short term biological asset.

IAS 41 tidak memperhatikan perlakuan akuntansi atas biological asset berdasarkan umurnya. Untuk beberapa jenis biological asset yang dimiliki kurang dari 1 (satu) tahun, pengukuran berdasarkan fair value dikurangi cost of sell akan sangat tidak berpengaruh. Hal tersebut dapat terlihat pada penyajian rekonsiliasi nilai tercatat dari perubahan fair value berdasarkan kondisi pasar tidak akan mempengaruhi laporan keuangan terutama income statement. Keadaan tersebut dikarenakan umur ekonomis short term biological asset jauh lebih singkat daripada periode akuntansi yang berlangsung.

Berdasarkan pada uraian tersebut maka penelitian ini akan memberikan paparan implementasi fair value terhadap asset biologis serta perbandingan, pengukuran dan implikasinya terhadap laporan keuangan dengan metode deskriptif kuantitatif.

\section{KAJIAN PUSTAKA}

\section{Mengukur Asset Biologis}

IFRS/IAS 41 merupakan standart akuntansi yang mempengaruhi paradigma nilai yang baru (kriteria penilaian nilai wajar) dalam bidang agrikultur. Elad and Herbohn (2011) analyzed the application of fair value in the agricultural sector (IAS 41) to agriculture companies from the UK, France, and Australia enforcement, through the analysis of annual report of small and medium. Findings show that financial statement 
lacked comparability do to the use of variety of valuation criteria under IAS 41 in the three countries. In companies' opinion fair value recognition cost outweigh is benefit and the impact of IAS 41 adoptionwas extremely reduced.

Maruli dan Mita (2010) yang mengatakan bahwa penerapan nilai wajar menyebabkan peningkatan nilai validitas laba dan perataan laba. Sedangkan Abdullah (2011); Pengukuran aset biologis berupa tanaman perkebunan pada PTPN XIV (Persero) diukur berdasarkan harga perolehan dipandang belum mampu memberikan informasi yang relevan bagi pengguna laporan keuangan.

Silva et al. (2012) cocluded that fair value adoption by Brazilian companies to measure biological assets turns decision - making processes more dificult. Historical cost was considered more reliable, more objective, and easier to perceive.

Fisher et al. (2010) findings corroborate this argument, indicating that the flexibility of IAS 41 allows for measurement at historical cost, which originates discrepancies in companies' earnings. However, Argiles et. al (2012), did not find any significant differences between the valuation of biological asset at historical cost and fair value when assesing future cash flows. However, result show more predictive power of future earnings under fair value model.

Widyastuti (2012) PT. Sampoerna Agro, Tbk mengakui asset biologisnya dengan menggunakan nilai wajar meskipun pada metode pengukurannya belum menggunakan nilai wajar. Sedangkan Farida (2013) menyatakan bahwa PTPN VII (Persero) dalam pengukuran asset biologis masih menggunakan harga perolehan. Sementara itu KUD Kota Boyolali tidak mengakui adanya sapi perah sebagai suatu aset atau aktiva dan tidak ada penyusutan atas sapi perah. Sapi perah tidak dimasukkan dalam kategori persediaan (Nastiti, 2013).

Abdullah (2011) melakukan penelitian tentang perlakuan akuntansi aset biologis PT. Perkebunan Nusantara XIV Makassar (Persero). Penelitian ini bertujuan untuk mengetahui perbandingan perlakuan akuntansi aset biologis pada PTPN XIV (Persero) dengan perlakuan akuntansi aset biologis berdasarkan IFRS.

Tyas dan Fachriyah (2011) melakukan evaluasi penerapan SAK ETAP dalam pelaporan aset biologis terhadap koperasi perkebunan "M". Data penelitian didapatkan melalui wawancara dengan beberapa narasumber dari koperasi "M" dan observasi ke 
lokasi penelitian untuk melihat kegiatan operasional terkait pengolahan aset biologis koperasi "M".

\section{Konsep Nilai Wajar}

Fair value adalah harga yang akan diterima untuk menjual aset atau dibayar untuk mentransfer kewajiban dalam transaksi teratur antara pelaku pasar pada tanggal pengukuran (IFRS 13 par. 5). Menurut IAS 41 par. 8 fair value dapat didefinisikan sebagai jumlah dari aset yang dapat dipertukarkan, atau kewajiban yang diselesaikan, antara pihak yang memadai, dan bersedia melakukan transaksi wajar (arm's length transaction).

IFRS 13 berusaha untuk meningkatkan konsistensi dan komparabilitas dalam pengukuran fair value dan pengungkapan terkait melalui "hirarki fair value". Hirarki memberikan prioritas tertinggi (disesuaikan) dengan harga yang dikutip pada pasar aktif untuk aset yang sama atau kewajiban dan input prioritas terendah untuk diamati (IFRS 13 par. 72).

Entitas menggunakan teknik penilaian yang tepat dalam situasi dimana data yang cukup tersedia untuk mengukur fair value, memaksimalkan penggunaan input yang relevan dan meminimalkan penggunaan input yang tidak teramati (IFRS 13 par. 61, IFRS 13 par. 67). Tujuan penggunaan teknik penilaian adalah untuk memperkirakan harga dimana transaksi teratur untuk menjual aset atau untuk mentransfer kewajiban yang akan terjadi antara pelaku pasar dan tanggal pengukuran dalam kondisi pasar saat ini.

Fair value memberikan informasi keuangan terkini yang lebih relevan sebagai dasar pengambilan keputusan. Fair value juga dapat memperbaiki transparasi laporan keuangan perusahaan dan meningkatkan keterbandingan laporan keuangan antar entitas. Apabila diterapkan dengan baik, fair value juga dapat mendekatkan konsep laba akuntansi, sehingga profil risiko dari suatu entitas diketahui dengan lebih baik. Adapun kelemahan fair value adalah kemungkinan nilai yang ada di pasar tidak menunjukkan nilai wajar karena pasar dianggap tidak atau kurang aktif, adanya kemungkinan "penggorengan" nilai pasar karena pasar tidak efisien dalam menyaring dan mengolah informasi, serta penggunaan penilaian alternatif, misalnya arus kas diskontoan yang bisa 
disebabkan ketidakprofesionalan penilai atau kesalahan yang tidak disengaja. Pasar yang over-reactive juga menyebabkan volatilitas earning entitas.

\section{Aktiva Biologis}

Aset adalah sumber daya yang dikendalikan oeh suatu entitas sebagai akibat peristiwa masa lalu dan dari aset tersebut diharapkan ada manfaat ekonomi masa depan yang mengalir ke dalam entitas tersebut (Giri, 2012:31). Menurut IAS 41 par. 5 yang dimaksud biological asset adalah tanaman atau binatang hidup. Entitas harus mencatat biological asset atau agricultural produce ketika, dan hanya jika (IAS 41 par. 10).

Entitas didorong untuk memberikan deskripsi yang dapat diukur untuk setiap kelompok biological asset, membedakan antara consumable dan bearer biological assets atau mature dan immature biological assets, yang sesuai. Sebagai contoh, entitas mungkin mengungkapkan nilai yang tercatat dari consumble biological asset dan bearer biological asset sebagai kelompok. Sebuah entitas mungkin membagi lebih lanjut nilai tercatat antara mature dan immature biological asset. Perbedaan ini memberikan informasi mungkin membantu menilai waktu arus kas masa depan. Entitas mengungkapkan dasar untuk membuat setiap perbedaan tersebut (IAS 41 par. 43).

\section{Industri Peternakan}

Menurut UU No. 18 Tahun 2009 tentang Peternakan dan Kesehatan Hewan, Perusahaan peternakan adalah perorangan atau korporasi, baik yang berbentuk badan hukum maupun yang bukan hukum, yang didirikan dan berkedudukan dalam wilayah Negara Republik Indonesia yang mengelola usaha peternakan dengan kriteria dan skala tertentu.

Dalam pengelolaan usaha industri peternakan, Bapepam (SE-02/PM/2002) menjelaskan bahwa terdapat beberapa risiko yang mungkin dihadapi industri peternakan, diantaranya: 1) Kesinambungan Hewan ternak dan Kondisi Pasar, 2) Tingkat Kompetensi \& Fluktuasi Harga, 3) Tingkat Kompetensi, 4) Risiko perubahan Teknologi, 5) Risiko pemogok Karyawan, 6) Risiko Leverage, 7) Risiko kebijakan pemerintah. 


\section{Kerangka Konseptual}

Dasar pengukuran yang digunakan dalam menilai biological asset sesuai dengan yang ditetapkan IAS 41 adalah fair value dikurangi cost of sell. Dalam pengukuran biological asset, IAS 41 tidak membedakan perlakuan akuntansi terhadap beberapa jenis biological asset yang mempunyai kriteria tertentu. Oleh karena itu, agriculture company sebagai perusahaan yang seharusnya menggunakan pedoman IAS 41 diharapkan dapat menerapkan dasar pengukuran fair value yang sesuai dengan sifat dan klasifikasi biological asset yang dimilikinya. Berikut kerangka konseptual pengukuran asset biologis yang dilakukan pada PT. Malindo Feedmill sebagai obyek penelitian.

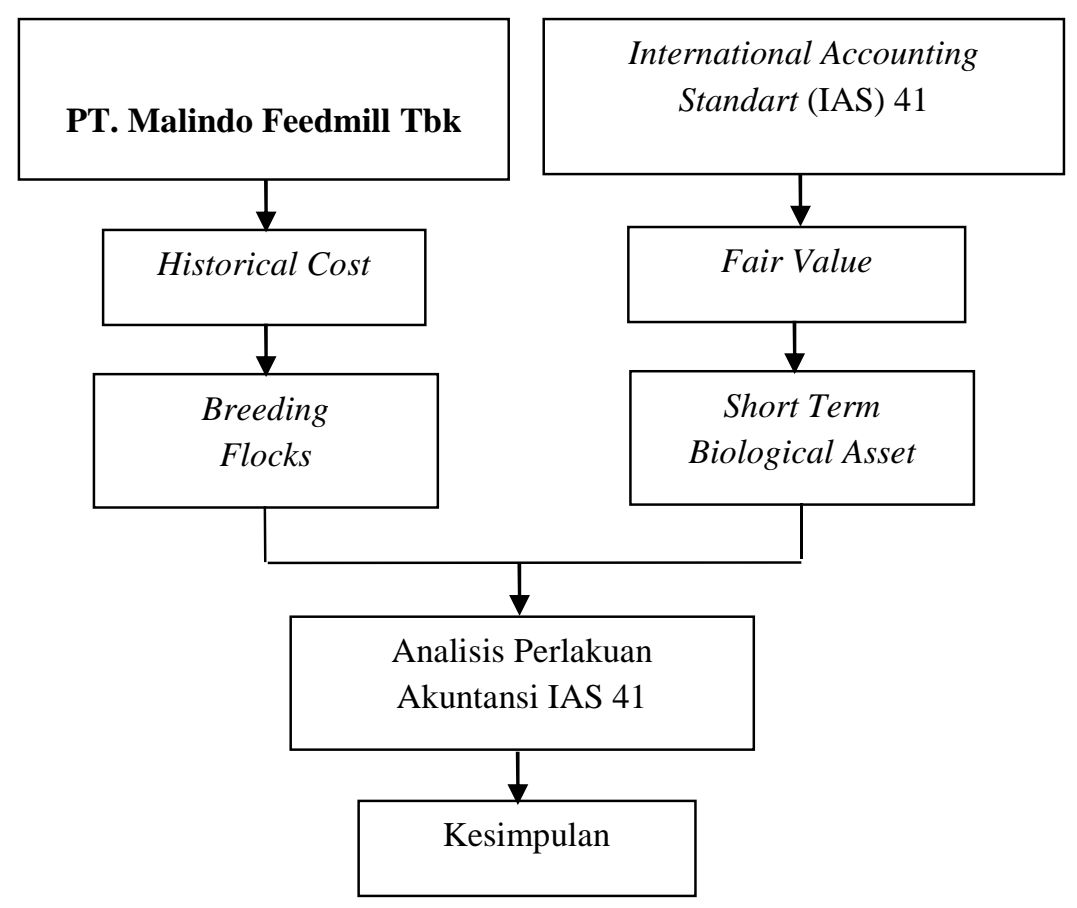

\section{Bagan 1. Kerangka Konseptual Penelitian}

\section{METODE}

\section{Lokasi dan Jenis penelitian}

Penelitian ini dilakukan pada PT. Malindo Feedmill Tbk dengan mengambil datadata berupa laporan keuangan yang terdapat pada website resmi perusahaan yaitu www.malindofeedmill.com. penelitian ini merupakan penelitian deskriptif, yaitu penelitian yang dilakukan untuk mengetahui nilai variabel mandiri, baik satu varibel 
atau lebih (independen) tanpa membuat perbandingan, atau menghubungkan dengan varibel lain.

\section{Jenis dan Sumber Data}

Data yang digunakan dalam penelitian ini berupa data kuantitatif yang berupa data keuangan yang diambil dari annual report PT Malindo Feedmill Tbk tahun 2014. Sumber data yang diperoleh berupa data sekunder yaitu berupa annual report PT. Malindo Feedmill Tbk yang terkait dengan biological asset dengan periode yang berakhir pada tahun 2014 .

\section{Metode Pengumpulan Data dan Anlisis Data}

Metode analisis data yang digunakan dalam penelitian ini adalah analisis deskriptif dengan pendekatan kuntitatif. Metode analisis data dalam penelitian ini bertujuan untuk memberikan gambaran yang cukup jelas tentang obyek yang diteliti serta menginterpretasikannya terkait dengan biological asset yang terdapat pada laporan keuangan yang dipublikasikan tahun 2014 PT. Malindo Feedmill Tbk.

\section{HASIL DAN PEMBAHASAN}

\section{Pelaporan Keuangan Terhadap Breading Flock PT Malindo Feedmiil}

Short term biological asset yang dimiliki PT. Malindo Feedmill Tbk yaitu berupa unggas yang meliputi telur tetas, itik, ayam pedaging, dan ayam pembibit. Pada PT. Malindo Feedmill Tbk, short term biological asset yang berupa hatching eggs (telur tetas), duck (itik) dan broiler (ayam pedaging) diakui sebagai iventory. Sedangkan breeding flocks mengakui adanya short term biological asset berupa ayam pembibit.

Pengakuan breeding flocks yang dilakukan oleh PT. Malindo Feedmill Tbk didasarkan pada masa tranformasi biologisnya meliputi Pre-productive breeding flocks (belum menghasilkan) dan productive breeding flocks (telah menghasilkan). Preproductive breeding flocks merupakan breeding flocks milik perusahaan yang masih dalam masa pertumbuhan, sedangkan apabila telah mencapai spesifikasi kedalam masa produksi maka perusahaan akan mereklasifikasikan dan mengakui pre-productive flocks menjadi productive flocks. 
Agricultural produce dari siklus produksi breeding flocks pada PT. Malindo Feedmill Tbk adalah Parent stock (ayam pembibit induk) dan Day old chick final stock (ayam umur sehari). Parent stock merupakan hasil produksi dari Grandparent stock (ayam pembibit nenek) yang dimiliki oleh perusahaan. Dalam hal ini grandparent stock merupakan induk dari parent stock yang hanya dikhususkan untuk memproduksi parent stock saja. Selanjutnya parent stock yang telah dihasilkan oleh grandparent stock akan memproduksi Day old chick final stock sebagai hasil panen yang siap untuk dijual.

Selain pengakuan breeding flocks pada masa transformasi biologisnya, PT Malindo Feedmill Tbk juga melakukan pengakuan terhadap ayam afkir (tidak produktif). Ketika productive breeding flocks telah mencapai batas usia produktif, maka perusahaan akan melakukan penghapusan terhadap breeding flocks tersebut. Pengukuran breeding flocks yang terdapat pada PT. Malindo Feedmill Tbk yang meliputi pre-productive breeding flocks dan productive breeding flocks berdasarkan historical cost. Pre-productive breeding flock diukur berdasarkan historical cost yang berasal dari harga bibit ayam ditambah kapitalisasi biaya yang dikeluarkan selama masa pertumbuhan. Sedangkan productive breeding flocks diukur berdasarkan historical cost pada saat reklasifikasi dari pre-productive breeding flocks dan dikurangi dengan depletion and unproductive chicken. PT. Malindo Feedmill Tbk mengungkapkan breeding flocks yang dimilikinya pada Laporan Posisi Keuangan dalam kelompok current asset. Hal ini dikarenakan masa manfaat (umur) dari breeding flocks kurang lebih dari 1 (satu) tahun sehingga dapat dikategorikan sebagai short term biological asset.

Pengukuran breeding flocks yang terdapat pada PT. Malindo Feedmill Tbk yang meliputi pre-productive breeding flocks dan productive breeding flocks berdasarkan historical cost. Pre-productive breeding flock diukur berdasarkan historical cost yang berasal dari harga bibit ayam ditambah kapitalisasi biaya yang dikeluarkan selama masa pertumbuhan. Sedangkan productive breeding flocks diukur berdasarkan historical cost pada saat reklasifikasi dari pre-productive breeding flocks dan dikurangi dengan depletion and unproductive chicken.

Pengungkapkan breeding flocks PT. Malindo Feedmill Tbk pada Laporan Posisi Keuangan dalam kelompok current asset. Hal ini dikarenakan masa manfaat (umur) dari breeding flocks kurang lebih dari 1 (satu) tahun sehingga dapat dikategorikan sebagai 
short term biological asset. Seperti yang telah diketahui bahwa breeding flocks dalam perusahaan telah dikelompokkan kedalam pre-productive breeding flocks (belum menghasilkan) dan productive breeding flocks (telah menghasilkan).

\section{Perbandingan Perlakuan Akuntansi Breeding Flocks menurut PT. Malindo Feedmill Tbk dengan IAS 41}

PT. Malindo Feedmill Tbk mengakui breeding flocks yang dimilikinya meliputi pre-productive breeding flocks dan productive breeding flocks masih berdasarkan konsep historical cost. Dasar pengukuran tersebut tentunya berbeda dengan yang telah ditetapkan IAS 41 par. 12 yang mengharuskan setiap biological asset dinilai berdasarkan fair value dikurangi cost of sell. Sehingga apabila PT. Malindo Feedmill Tbk menerapkan IAS 41 sebagai pedoman pengukuran biological asset, maka perusahaan tersebut harus mengakui dan mengukur breeding flocks yang dimilikinya sesuai dengan konsep fair value. Menurut IAS 41 par. 15, penentuan fair value dari breeding flocks sesuai dengan harga penawaran di pasar yang disesuaikan dengan lokasi dan kondisi dari biological asset tersebut.

Setelah melakukan perhitungan breeding flocks sesuai konsep fair value yang ditetapkan IAS 41 yang kemudian dibandingkan dengan konsep historical cost yang dilakukan oleh PT. Malindo Feedmill Tbk, terdapat beberapa perbedaan yang dapat dianalisa oleh peneliti diantaranya sebagai berikut:

1) Saldo awal pre-productive breeding flocks

a) Grandparent stocks

Pencatatan saldo awal grandparent stocks berupa day old chick dalam preproductive breeding flocks sesuai PT. Malindo Feedmill Tbk adalah Rp 10.151.793.000 yang dinilai berdasarkan historical cost. Berbeda halnya apabila perusahaan menerapkan IAS 41, maka terdapat perbedaan pencatatan yang terjadi atas saldo awal grandparent stocks menjadi Rp 18.704.000.000.

b) Parent stocks

Perbedaan pencatatan juga terjadi pada parent stocks, dimana sebelumnya PT. Malindo Feedmill Tbk mengakui saldo awal parent stocks senilai Rp 52.260.809.000. Sedangkan pencatatan tersebut berbeda IAS 41 diterapkan yang menyebabkan saldo awal parent stocks menjadi Rp 95.390.400.000. 
Perhitungan saldo awal grandparent stock diperoleh dengan asumsi kapasitas produksi untuk menghasilkan parent stock yaitu 3.200.000 ekor. Sedangkan saldo awal parent stock sebesar 16.320.000 ekor diperoleh dari perbandingan antara saldo awal grandparent stock dengan saldo awal parent stock dalam annual report 2014 dikalikan dengan saldo awal grandparet stock. Peneliti menggunakan market price sebagai dasar penentuan fair value untuk DOC grandparent stock dan parent stock senilai Rp 5.845/ekor sesuai dengan Dinas Peternakan Provinsi Jawa Barat.

Secara keseluruhan, terdapat perbedaan yang cukup signifikan perhitungan saldo awal pre-productive breeding flocks antara PT. Malindo Feedmill Tbk dan IAS 41. Apabila perusahaan menggunakan IAS 41 maka akan terjadi peningkatan pengakuan saldo awal pre-productive breeding flocks senilai Rp 56.339.660.000 yang diperoleh dari kenaikan saldo awal grandparent stock senilai Rp 9.640.743.000 dan kenaikan saldo awal parent stock senilai Rp 46.698.917.000. Pengakuan awal day old chick dari pre-productive breeding flocks sebenarnya telah sesuai dengan pedoman IAS 41 yang didasarkan pada market price dari biological asset tersebut. Adapun selisih hasil perhitungan pre-productive breeding flocks tersebut terletak pada perbedaan dalam penentuan market price, dimana IAS 41 selalu mengakui perubahan fair value berdasarkan fluktuasi dari pasar.

Perhitungan saldo awal pre-productive breeding flocks berdasarkan IAS 41 melaporkan nilai yang lebih tinggi daripada perhitungan PT. Malindo Feedmill Tbk yang menggunakan historical cost. Perbedaan saldo awal pre-productive breeding flocks tersebut secara tidak langsung akan mempengaruhi pelaporan nilai tercatat dari current asset dalam financial position statement. Seperti yang diketahui bahwa current asset merupakan asset perusahaan yang diharapkan akan dijual, ditagih atau digunakan selama satu siklus operasi perusahaan. Sehingga peningkatan atas pelaporan current asset tersebut menunjukkan bahwa tingkat likuiditas perusahaan dalam memenuhi/membayar liabilities yang dimilikinya pada saat ditagih juga akan semakin meningkat.

2) Kapitalisasi Biaya

a) Grand Parent stock

Kapitalisasi biaya PT. Malindo Feedmill berbeda ketika perusahaan menerapkan IAS 41, nilai kapitalisasi biya tersebut meiputi biaya pakan ternak dan vaksin atau obat- 
obatan. Kapitalisasi biaya menurut PT. Malindo Feedmill Tbk adalah senilai Rp 45.641.237.000. Sedangkan saldo kapitalisasi tersebut berbeda ketika perusahaan menerapkan IAS 41 yang menjadi Rp 51.520.000.000.

b) Parent stock

Perhitungan atas kapitalisasi biaya tersebut pada dasarnya sama dengan grandparent stocks, hanya saja hasil perhitungan kapitalisasi parent stocks senilai Rp 262.752.000.000 nantinya harus ditambahkan dengan hasil perhitungan kapitalisasi dari grandparent stocks senilai Rp 51.520.000.000. Hal ini dikarenakan kapitalisasi biaya grandparent stocks merupakan biaya yang dikeluarkan pada saat memproduksi parent stocks, sehingga biaya tersebut juga melekat dan dicatat pada saat pengakuan awal parent stocks.

Perbandingan hasil perhitungan kapitalisasi biaya antara PT. Malindo Feedmill Tbk dan IAS 41 terdapat kenaikan yang sangat signifikan senilai Rp 57.023.921.000 yang diperoleh dari kenaikan kapitalisasi biaya grandparent stock senilai Rp 5.878.763.000 serta kenaikan kapitalisasi biaya atas parent stock senilai Rp 51.145.158.000. Perbedaan tersebut dikarenakan ketidaksamaan dalam menetapkan tarif biaya pakan ternak dan biaya vaksin (obat-obatan) atas breeding flocks. Adanya kenaikan kapitalisasi biaya atas pre-productive breeding flocks akan berdampak juga pada factory overhead yang juga akan naik. Kenaikan factory overhead sebagai salah satu komponen manufacturing cost secara langsung akan mempengaruhi pelaporan atas cost of goods sold dalam comprehensive income statement.

Pengungkapan deskripsi perhitungan untuk setiap kelompok biological asset yang dilakukan perusahaan telah sesuai dengan IAS 41 par. 43. Perusahaan juga telah mengklasifikasikan breeding flocks sesuai dengan IAS 41 meliputi pre-productive breeding flocks dan productive breeding flocks. Dasar pengklasifikasian ini sesuai dengan IAS 41 par. 45 yang mengkategorikan biological asset sebagai mature biological asset (sudah dewasa) dan immature biological asset (belum dewasa).

Selain pengungkapan dalam financial statement, IAS 41 par. 50 mengharuskan entitas mengungkapkan rekonsiliasi perubahan jumlah tercatat dari biological asset. Rekonsiliasi tersebut meliputi peningkatan karena purchases, penurunan karena sales, dan perubahan fair value dikurangi cost of sell. Perubahan fair value dikurangi cost of sell menurut IAS 41 par. 51 disebabkan karena perubahan fisik dan market price. 
Namun, kondisi ini tentunya tidak sesuai apabila diterapkan PT. Malindo Feedmill Tbk karena breeding flocks memiliki siklus produksi yang lebih singkat daripada periode akuntansi yang berlangsung.

\section{Dampak Penerapan Fair Value terhadap Breeding Flocks pada PT. Malindo Feedmill Tbk}

International Accounting Standard (IAS) 41 merupakan standar IFRS yang mengatur perlakuan akuntansi yang terkait dengan agricultural activity meliputi biological asset dan agricultural produce. Dasar pengukuran yang digunakan sesuai dengan IAS 41 adalah konsep fair value. Menurut IAS 41 par. 12 menjelaskan bahwa seluruh biological asset harus diukur berdasarkan fair value dikurangi dengan cost of sell. Permasalahannya, dalam IAS 41 tidak membedakan perlakuan fair value terhadap beberapa kategori biological asset. Hal ini tentunya kurang relevan apabila diterapkan terhadap beberapa jenis biological asset, misalnya seperti short term biological asset.

Beberapa dampak yang ditimbulkan dari penggunaan fair value terhadap breeding flocks adalah 1) Peningkatan current asset; Pengukuran breeding flock berdasarkan konsep fair value pada dasarnya merupakan pengukuran yang sesuai dengan kondisi pasar yaitu sesuai dengan IAS 41 par. 7. Ketika IAS 41 diterapkan, perusahaan melaporkan nilai tercatat dari pre-productive breeding flocks lebih tinggi daripada yang dilaporkan PT. Malindo Feedmill Tbk. Perbedaan tersebut secara tidak langsung akan mempengaruhi total current asset. Kenaikan current asset secara tidak langsung mempengaruhi tingkat likuiditas perusahaan dimana nilai current asset lebih besar dari pada current liabilitas. 2) Peningkatan cost of good sold; Kapitalisasi biaya yang dikeluarkan pre-productive breeding flocks dan depletion and unproductive chicken merupakan faktor yang mempengaruhi fluktuasi nilai cost of goods sold, Kenaikan dari cost of goods sold tersebut secara langsung akan berdampak pada penurunan gross profit. 3) Pengungkapan Rekonsiliasi Short Term Biological Asset; Penggunaan mark to market ini akan menyebabkan adanya perubahan secara terus-menerus pada financial statement perusahaan ketika nilai asset tersebut mengalami kenaikan dan penurunan. Apabila IAS 41 diterapkan, perusahaan harus melaporkan gain atau loss atas perubahan fair value selama periode pengakuan awal sampai masa panen breeding flocks. Pengakuan selisih perubahan fair value tersebut akan berdampak pada meningkatnya voliditas kinerja keuangan yang sebetulnya belum terealisasi. 


\section{SIMPULAN}

Berdasarkan hasil analisis data dan pembahasan maka dapat diambil kesimpulan dalam penelitian ini adalah Penggunaan konsep fair value terhadap pengukuran breeding flocks menyebabkan terjadinya peningkatan current assets, cost of goods sold perusahaan, serta pengungkapan rekonsiliasi. Peningkatan current assets tersebut berasal dari nilai tercatat dari breeding flocks dalam financial position statement. Sedangkan peningkatan cost of goods sold diperoleh dari peningkatan kapitalisasi biaya pre-productive breeding flocks dan kenaikan depletion and unproductive chicken yang dilaporkan dalam comprehensive income statement. Dampak dari peningkatan terhadap kedua komponen tersebut akan mempengaruhi fluktuasi keuntungan yang nantinya akan diperoleh perusahaan.

Dalam konsep fair value mengharuskan perusahaan menggunakan market price sebagai dasar pengukuran breeding flocks. Sehingga perusahaan harus selalu mencatat dan mengungkapkan perubahan fair value yang terjadi atas breeding flocks. Perubahan fair value tersebut meliputi perubahan fisik dan market price dari breeding flocks yang harus disajikan dalam rekonsiliasi nilai tercatat dari breeding flocks. Pengungkapan rekonsiliasi tersebut mempengaruhi intensitas pelaporan keuangan yang dikarenakan siklus produksi breeding flocks lebih singkat daripada periode akuntansi yang berlangsung. IAS 41 belom relevan diterapkan di PT Malindo Feedmill Tbk karena IAS 41 tidak melakukan pengelompokan asset biologis berdasarkan umur atau siklusnya.

\section{DAFTAR RUJUKAN}

Abdullah, A. (2011). Perlakuan Akuntansi Aset Biologis PT. Perkebunan Nusantara XIV Makassar (Persero). Makassar. Universitas Hasanuddin.

Argiles, J., Aliberch, A. \& Blandon, J. 2012. A Comparative study of difficulties in accounting preparation and judgement in agriculture using fair value and historical cost for biological assets valuation. Spanish Accounting Review, 15 (1), pp. 109-115.

Bapepam. (2002). Pedoman Penyajian dan Pengungkapan Laporan Keuangan Emiten atau Perusahaan Publik: Industri Peternakan. Jakarta.

Brogg, S. (2012). Panduan IFRS Edisi Revisi. Jakarta. Indeks.

Choi, F. D. S. \& Meek, G. K. (2005). International Accounting, Edisi 5 (Lima). Jakarta. Salemba Empat.

Dinas Peternakan. (2015). Trend Harga Komoditi Provinsi Jawa Barat. (htttp://www.disnak.jabarprov.go.id/index.php/info_harga_harian/viewRekapRan ge2, diakses tanggal 15 Agustus 2015). 
Elad, C., \& Herbohn, K. (2011). Implementing Fair Value Accounting in the Agricultural Sector. London: The Institute of chartered Accountants of Scotland.

Fisher, R., Mortensen, T. \& Webber, D. (2010). Fair value accounting in the agricultural sector: an analysis of financial statement preparers perception before and after the introduction of ias 41 agriculture. Accounting and Finance Association of Australia and New Zealand (AFAANZ) Conference, Christchurch, 4-6 July, at: www.afaanz.org/openconf/2010/modules/request.php.

Farida, I. (2013). Analisis Perlakuan Akuntansi Aset Biologis Berdasarkan International Accounting Standard 41 pada PT. Perkebunan Nusantara VII (Persero). Surabaya. Universitas Negeri Surabaya.

Giri, E. (2012). Akuntansi Keuangan Menengah 1 Perspektif IFRS. Yogyakarta. UPP STIM YKPN.

Greuning, H. (2005). International Financial Reporting Standarts: A Practical Guide. Jakarta: Salemba Empat.

IAI. (2009). Fair Value, Shifting Paradigm: Hisorical Cost to Fair Value. Akuntan Indonesia Edisi No. 16.

Mackenzie, B., et al. (2012). IFRS for SMEs untuk Usaha Kecil Menengah atau Entitas Tanpa Akuntabilitas Publik. Terjemahan Priyo Darmawan. Jakarta: Indeks.

Maruli, S. \& Mita, A. F. (2010). Analisis Pendekatan Nilai Wajar dan Nilai Historis dalam Penilaian Aset Biologis Perusahaan Agrikultur: Tinjauan Kritis Rencana Adopsi IAS 41. Purwokerto: SNA XII.

Nastiti, D. (2013). Deplesi Aset Biologis Pada Peternakan Sapi Perah KUD Kota Boyolali. Semarang: Universitas Dian Nuswantoro.

Purba, M. (2010). International Financial Reporting Standards Konvergensi dan Kendala Aplikasinya di Indonesia. Yogyakarta: Graha Ilmu.

Oliveira, J., Silva, A., \& Santos, V. (2015). Fair value: Model proposal for the dairy sector. Retrieved from www.emeraldinsight.com/0002-1466.htm

Sonbay, Y. (2010). Perbandingan biaya historis dan nilai wajar. Kajian Akuntansi, 2 (1).

Stickney, C. P., Well, R. L., Schipper, C. \& Francis, J. (2006). Financial Accounting: An Introduction to Concept, Methods and Uses. Natorp Boulevard Mason, $\mathrm{OH}$ : South-Western Cengage Learning.

Sukmadinata, N. S. (2013). Metode Penelitian Pendidikan. Bandung. PT. Remaja Rosdakarya.

Sugiyono. (2009). Statistika Untuk Penelitian. Bandung: Alfabeta.

Sugiyono. (2012). Metode Penelitian Kuantitatif, Kualitatif dan R\&D. Bandung: Alfabeta.

Suwardjono. (2012). Teori Akuntansi: Perekayasaan Pelaporan Keuangan. Edisi Ketiga. Yogyakarta: BPFE.

Tyas, E. \& Fachriyah, N. (2012). Evaluasi Penerapan Standar Akuntansi Keuangan dalam Pelaporan Aset Biologis (Studi Kasus Pada Koperasi “M”). Malang: Universitas Brawijaya.

Widyastuti, A. 2012. Analisis Penerapan International Accounting Standard (IAS) 41 pada PT. Sampoerna Agro, Tbk. Semarang: Universitas Diponegoro.

Hewan. Jakarta.

2009. Undang-Undang No. 18 tentang Peternakan dan Kesehatan 